\title{
Tracking nature - the possibilities of introducing permaculture strategies into the historical city centre of Zamość. The Courtyards
}

\author{
Katarzyna Kielin \\ wb.sekretariat@pollub.pl
}

Department of Architecture and Urban Planning, Faculty of Civil Engineering and Architecture Lublin University of Technology, Nadbystrzycka 40, 20-618 Lublin

\begin{abstract}
The author focuses on the problem of water management in the selected areas and the most adequate, appropriate, relative SUDS solutions for the places in question. The spaces were chosen from the area which was regarded as the most problematic in 'The Local Revitalisation Program for Zamość for the period 2017 to 2023'. Justification for the chosen solutions is based on the geological conditions of the terrain, the existing stormwater management system, the extent of paved surfaces and the quality and quantity of plant cover. Proposed solutions were analysed in the spotlight of permaculture principles. The aim of the paper is to raise awareness of the concepts of SUDS and Permaculture as they complement each other and offer pro-ecological approach to water
\end{abstract}

Keywords: water, sustainability, rain garden, Zamość, revitalisation.

\section{Introduction}

\section{What is permaculture?}

Permaculture design aims at following creative, ethical approach to the environment. Key figures who coined the concept of 'permaculture' in 1970' were Bill Mollison and David Holmgren who first applied the term to characterize enduring and self-preserving species of plants and animals beneficial to men [13]. They described it as „ an integrated, evolving system of perennial or self-perpetuating plant and animal species useful to man"[Mollison \& Holmgren, 1978]. Permaculture actions oscillate around the notion of conscious mimicry of structures, processes found in nature itself and go hand in hand with a contemporary strive for sustainable development of cities, villages and farmlands. At the very beginning, the permaculture principles were exploited in connection with Land and Nature Stewardship [13]. Most recent perspective on permaculture is the one which presents it as a design system used not only in the domains of harvesting, soil or water management, farming or gardening but also sustainable living - 'human organization' [13]. One of the main prerequisites of permaculture is a constant strive for a homeostatic relation of men and nature. In his 'Essence of Permaculture A summary of permaculture concepts and principles taken from 'Permaculture Principles and Pathways Beyond Sustainability', David Holmgren observed that permaculture strategies used to be exploited in mostly agricultural environment, whereas they are applicable in different domains, including cultural. He sees it as a much broader term. The movement relies strongly on a cooperative practices of a community, strengthens the role of individuals as responsible participants and contributors to healthy, ecological lifestyles and ecosystems. The integrity of man and their surroundings is tightened by means of simple, not revolutionary but evolutionary actions inspired by nature. Permaculture is strongly community - oriented movement with a great 
role of humans as strategic contributors to the sustainable development. It has been observed that people with a strong relation to their home place and community are more inclined to introduce permaculture ideas [18]. Permaculture principles revolve around seven major domains such as Land and Nature Stewardship, Built Environment, Tools \& Technology, Culture \& Education, Health \& Spiritual Well-Being, Finances \& Economics, Land Tenure \& Community

(Based on 'Essence of Permaculture A summary of permaculture concepts and principles taken from 'Permaculture Principles and Pathways Beyond Sustainability', David Holmgren)

Apart from these core domains there are also side issues falling under the notion of permaculture such as, for example: LETS - local exchange trading systems, Keyline water harvesting, bicycle transport, SUDS (Sustainable Urban Drainage System) [11]. One of the 'founding fathers' of the concept, David Holmgren, solidified twelve principles of permaculture design [Holmgren, 2007]. Having that in mind, I would like to look through selected town centre areas focusing on one aspect, namely the management of water - the existing state of the matter as well as possible, minor alterations to the places in question.

\section{'Green' v. 'grey' infrastructure}

Permaculture design solutions are compatible with the notion of green infrastructure. They both draw from nature, whereas the so-called 'grey' infrastructure refers to closed, engineered systems of stormwater collection and distribution such as pipes, drains, drainage wells, pumps. Technical solution predominance is what characterizes 'grey' infrastructure with frequent maintenance checks, the use of artificial materials such as PVC, PEHD, sometimes complicated, hazardous groundworks which alter the original stratification of geological soil layers, natural ground density, plasticity, or change groundwater conditions. Pumping stations' operation requires significant energy input.

Before the actual comparison of the two aproaches to the management of landscape elements it is reasonable to briefly explain the terms. The first - green - refers to man-made or natural ecosystem elements of a landscape which contribute to a human well-being by fostering ecological practices, preventing or halting, absorbing the outcomes of natural disasters such as floods, draughts, storm surges. Among the aims of green infrastructure are restoration of degraded natural habitats, biodiversity boost, the provision of the most efficient amenities that would collect, reuse, purify water, gather natural energy. Bettering the quality of urban public spaces seems to be too often overlooked and diminshed due to robust, consumerist surge in dense land overbuilding. Green infrastructure favours integrating rather than segregating. Applying permacultural thinking, nature is a system of interrelated, influential elements (including humans) where entities in order to sustain relevant equlibrium must stay in reciprocal relation. When you take, you must give something in return, this is a healthy, fair approach to environment. If you decide to build up a particular land, introduce building development to a land distorting natural connections within the system, it is fair, advisable to just make up for the loss created. Green infrastructure is highly beneficial on several domains: environmental, social, to name a few. Among many advantages there are for example [18]: rainwater harvesting, retention, smart distribution and natural purification, Soil erosion prevention, Better land quality, Human physical and mental healthcare improvement, Jobs' provision, Elevating city aesthetics by the introduction of green spaces, Promoting recreation, sports culture, Educating on pro-eco way of living, Strengthening a sense of community as co-responsible for the creation and maintenance of the most immediate, local surroundings, Enlarging, restoring, preserving, uplifting biodiversity, Reducing urban heat island effects, Permeability enhancement, Battling some impediments caused by ongoing climate change, Seeing potential and restoring dilapidating, post-industrial areas into green zones.

Green spaces are suitable for being green infrastructure components so long as they are a part of inteconnected network where 'green' also stands for something additional, meaning creating networks, green corridors. Investing in planting new trees, the implementation of additional plant cover could have this suplementary quality of creating infiltration, introducing hydrophyte species thus improving permeability of soil, the quality of rainwater or preventing excessive runoff. 


\section{SUDS (Sustainable Urban Drainage System)}

One of major branches of permaculture is the sustainable water management. Sustainable Urban Drainage System (SUDS) [11]. This concept proposed taking into consideration natural water flow mechanisms and probable chances of water infiltration characteristics. Urbanization processes are directly correlated with a relatively common paving practices resulting from auto-oriented society habits. Bus transfer facilities/ transit are still fairly underestimated and scarce. Since road infrastructure requires highly developed car traffic systems green, biodiverse areas have been gradually depleted and reconfigured. Due to greater surfaces being paved, the widespread phenomenon of impermeabilization occurs. Rain water inflow is acutely impeded by compacted structure of road layers. Soil undergoes the process of densifying. What is more, road investments tend to destabilize natural water run offs at the same time disturbing natural soil composition.

\section{Courtyards}

One of the most characteristic features of the Zamość town centre is the existence of inward courtyards located primarily on the east side of the Great Market Square. Despite their undoubted potential, their function is largely undetermined, unclarified. Tenement houses surrounding the courtyards provide residential spaces for the citizens who do not make enough use of the space they have at their disposal. The buildings and the courtyards are accessible from the outside streets, via gateways. The ground floor parts of the houses provide small vending and service spaces (accessible from the main streets) with the residential units being situated on the upper floors. Social interactions within the courtyards tend to be scarce, random. No sense of community could be observed, reflected in taking care of the space around.

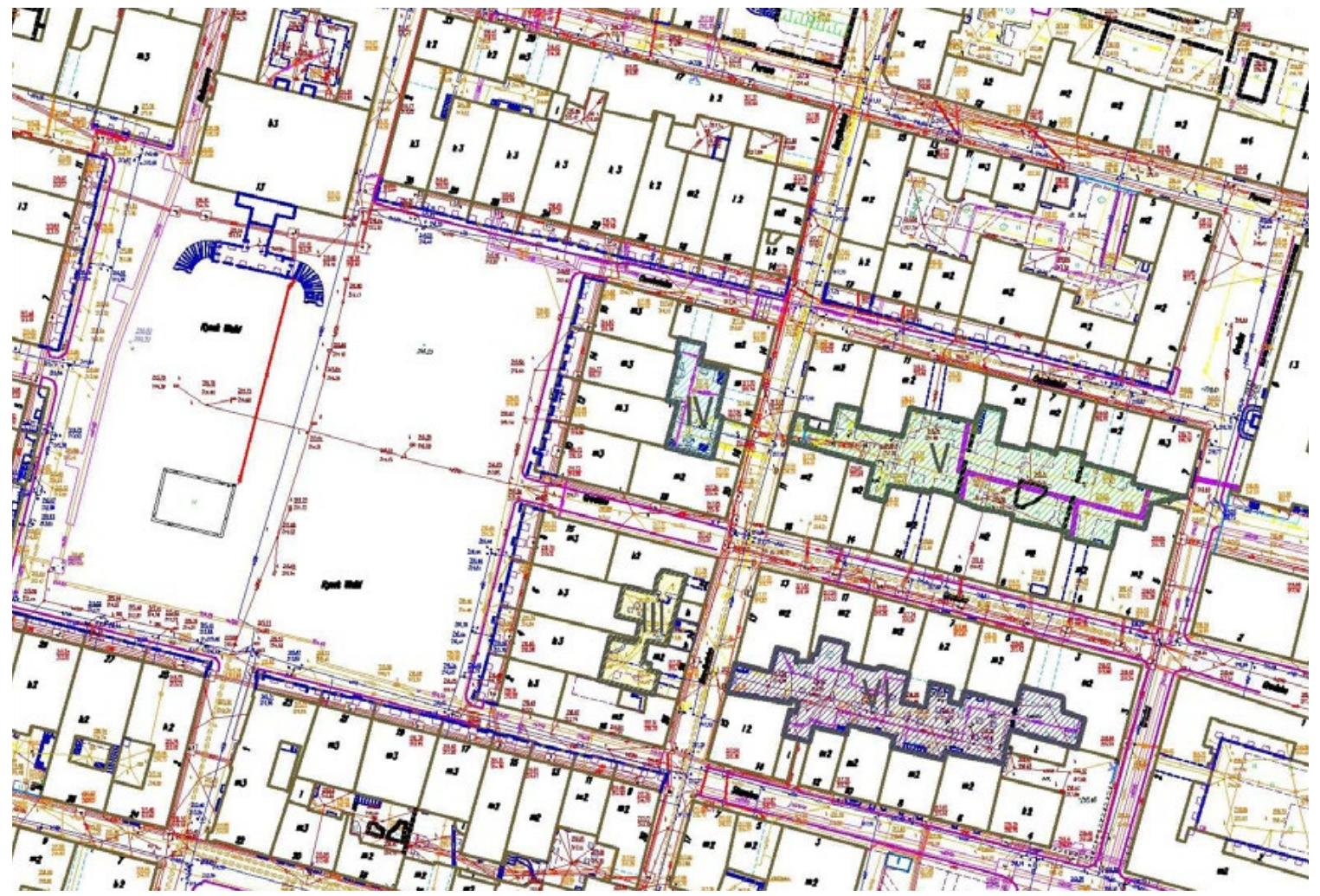

Fig. 1. Courtyards; Source: author's own material 


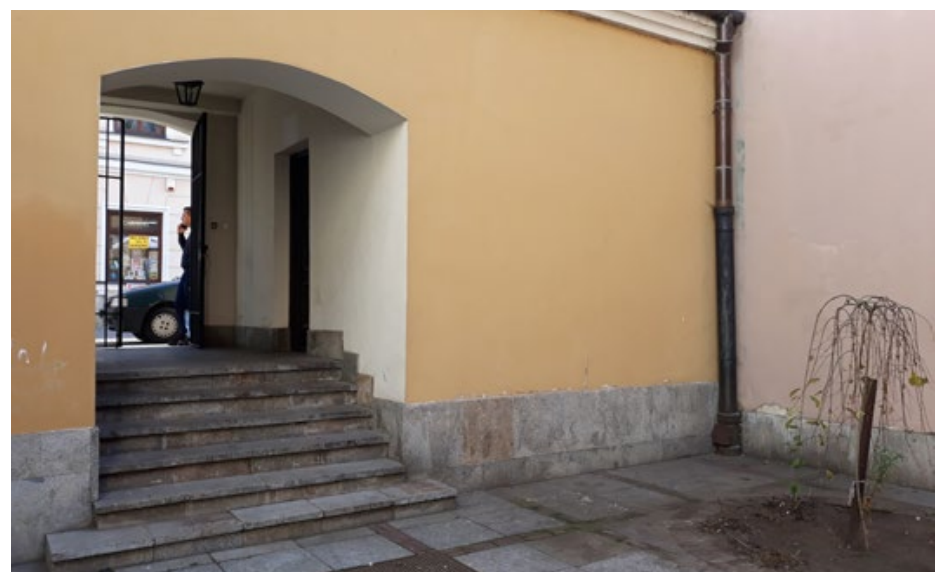

Fig. 2. Courtyard No. III, Lowered surface of the courtyard; Source: author's own photo

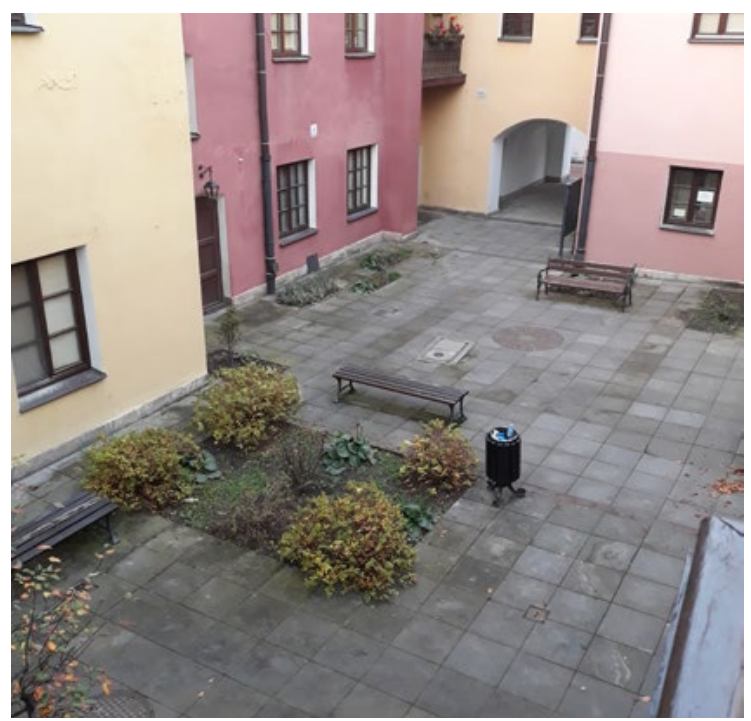

Fig. 4. Courtyard No. IV, Bird's-eye view on the Courtyard and the positioning of green slots; Source: author's own photo

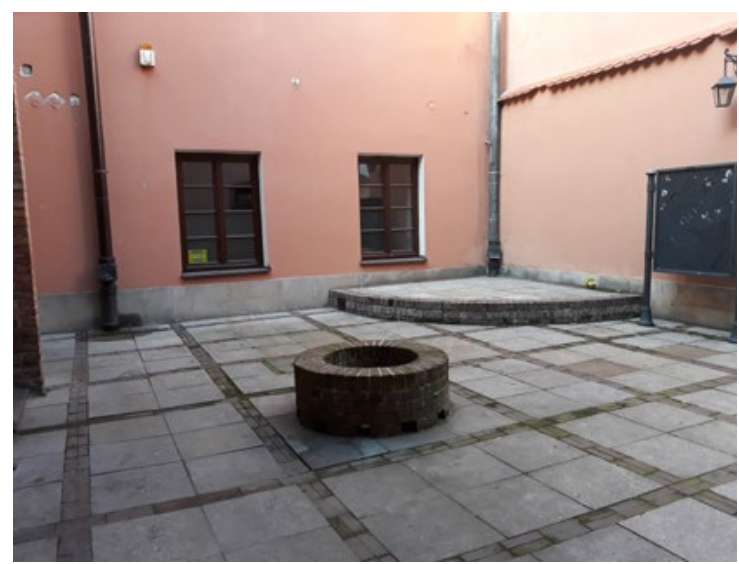

Fig. 6. Courtyard No. III, Enclosed space, potentially high risk of urban flooding; Source: author's own photo own photo

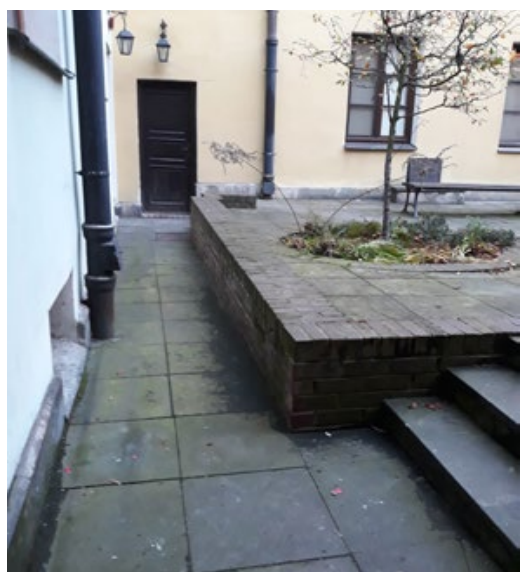

Fig. 3. Courtyard No. IV, Lowered parts of the courtyard; Source: author's own photo



Fig. 5. Courtyard No. VI, Access to the courtyard spaces provided by gateways (1-2); Source: author's own photo

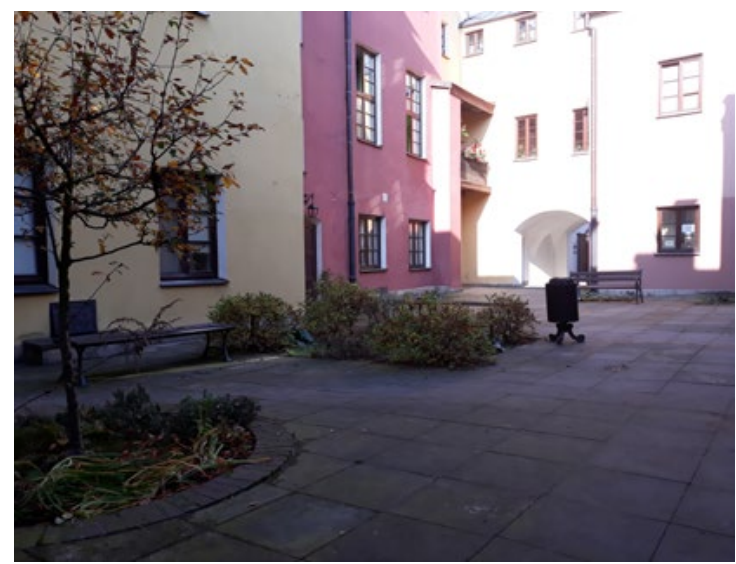

Fig. 7. Courtyard No. IV, Sun exposure, ; Source: author's 
Terrain work related to the common features and spatial organisation of the couryards were carried out in October and November 2018. The location of the analysed places is presented on the map showing the Zamość historical centre.

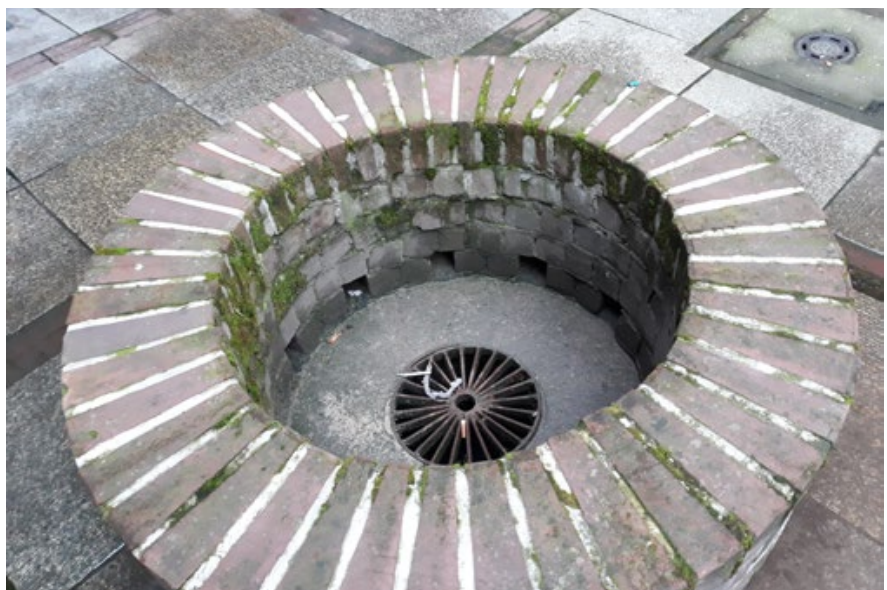

Fig. 8. Courtyard No. III, sewerage inlet built over by a brick circular piece of small architecture; Source: author's own photo

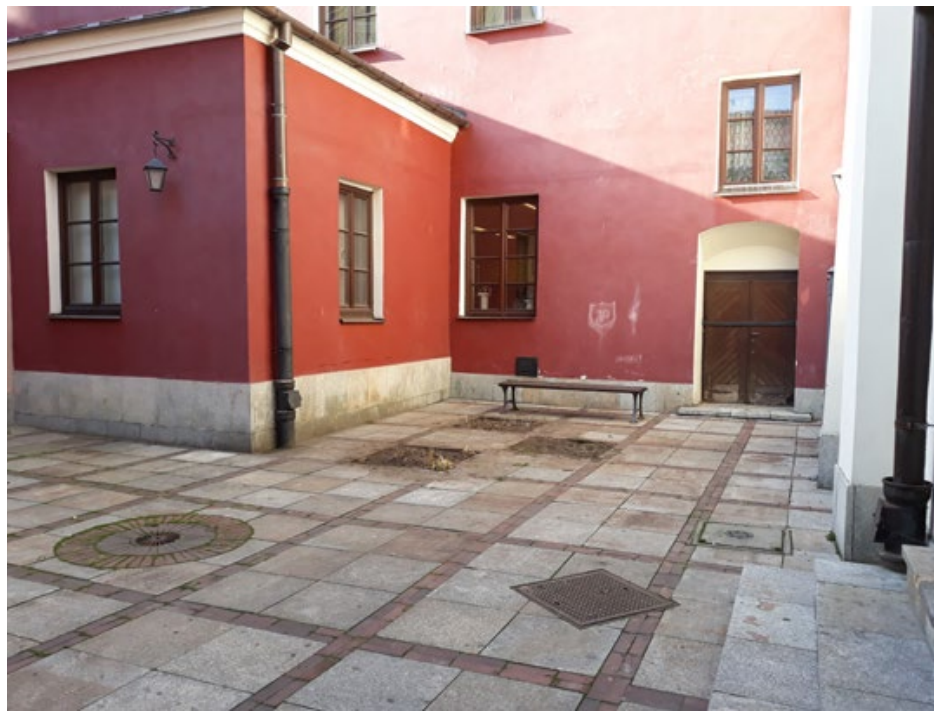

Fig. 10. Courtyard No. III, Extensive pavement contributes to more rapid water run off; Source: author's own photo

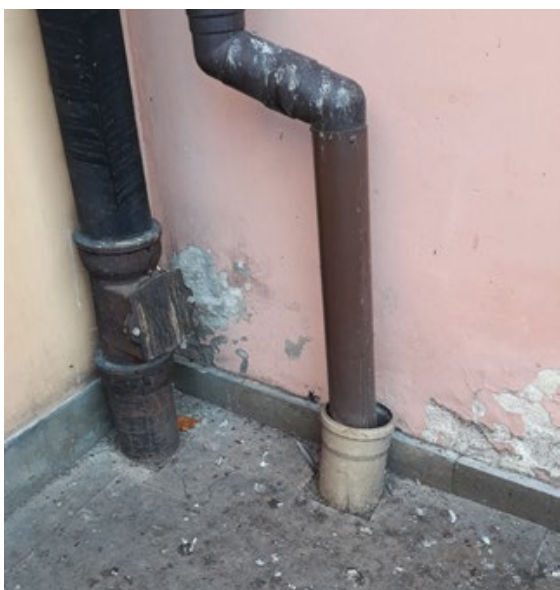

Fig. 9. Courtyard No. VI Down pipes 'sinking' beneath the ground connected to sewerage closed system; Source: author's own photo

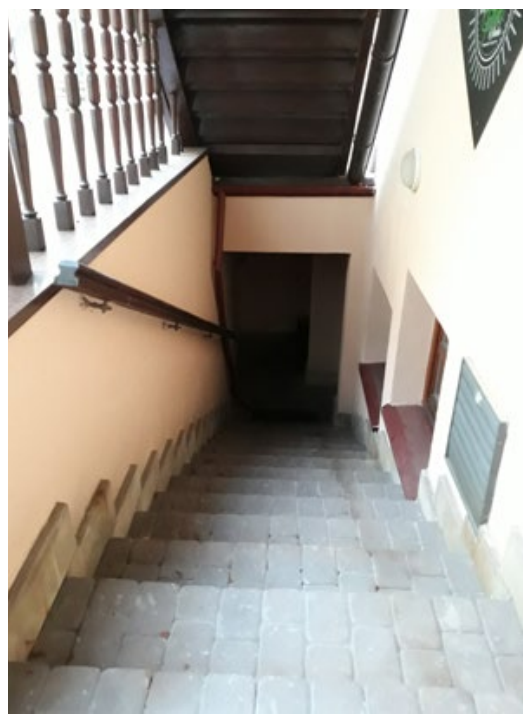

Fig. 11. Courtyard No. IV Steep basement staircases; Source: author's own photo

\section{Common spatial characteristics:}

- Relative proximity to a central part of a historical town - The Great Market Square

- They all fall under strictly delimited outline of streets, intersecting ortogonally: Zamenhofa, Pereca, Ormiańska, Grodzka, Staszica following east-west direction and the edge of Great Market Square, Bazyliańska, Grecka, enclosing Waleriana Łukasińskiego heading from south to north

- The inside of the quarters are of irregular shape with some parts of the housing entering, 'protruding' from the main volume

- The inside space is sometimes divided into smaller parts by means of walls with window and door openings; the division tends to be situated at the boundary between two neighbouring buildings 
- The spaces are approachable by means of more than one gateways which sometimes differ in level with the rest of the space (difference of several steps, with the courtyard area lowered in relation to the entrance)

- The bigger ones are longitudinally arranged, the smaller yards direct towards the relation north - south

- Enclosed spaces which in case of abrupt, heavy downfalls may be in danger of sudden overflooding, basement levels accessible from the inward courtyards through plunged, grated basement windows

- The organisation of window openings follows north - south direction which is valid in terms of capturing the sun

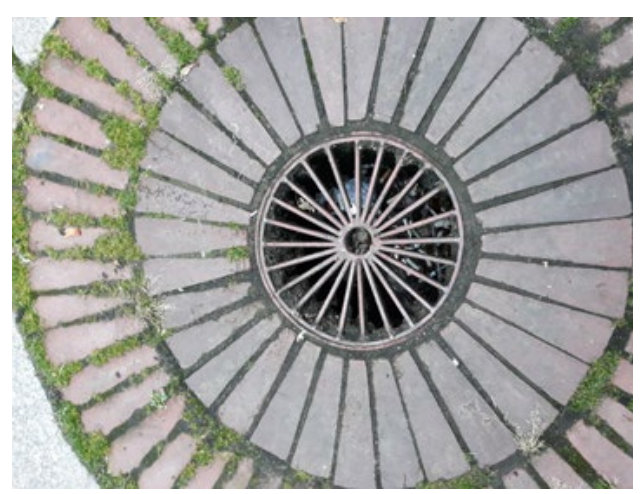

Fig. 12. Courtyard No. III, Clotted, 'blocked' inlet to the existing water drain; Source: author's own photo

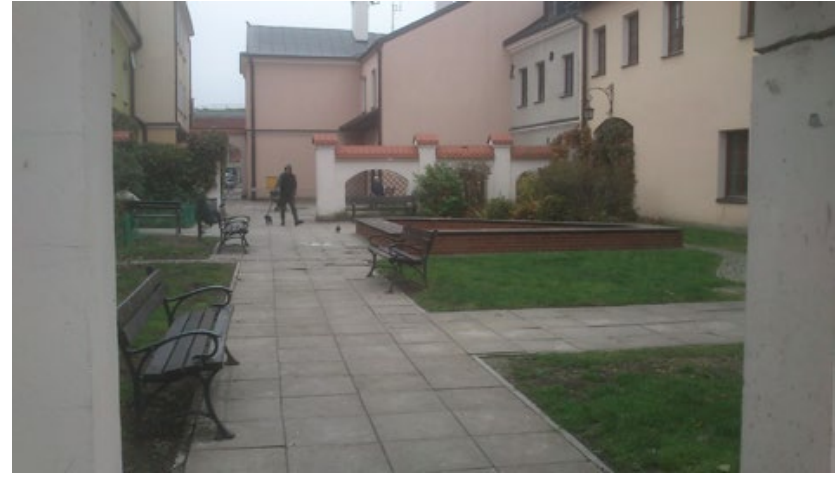

Fig. 13. Courtyard No. V, paved impermeable surfaces of the sidewalks; Source: author's own photo

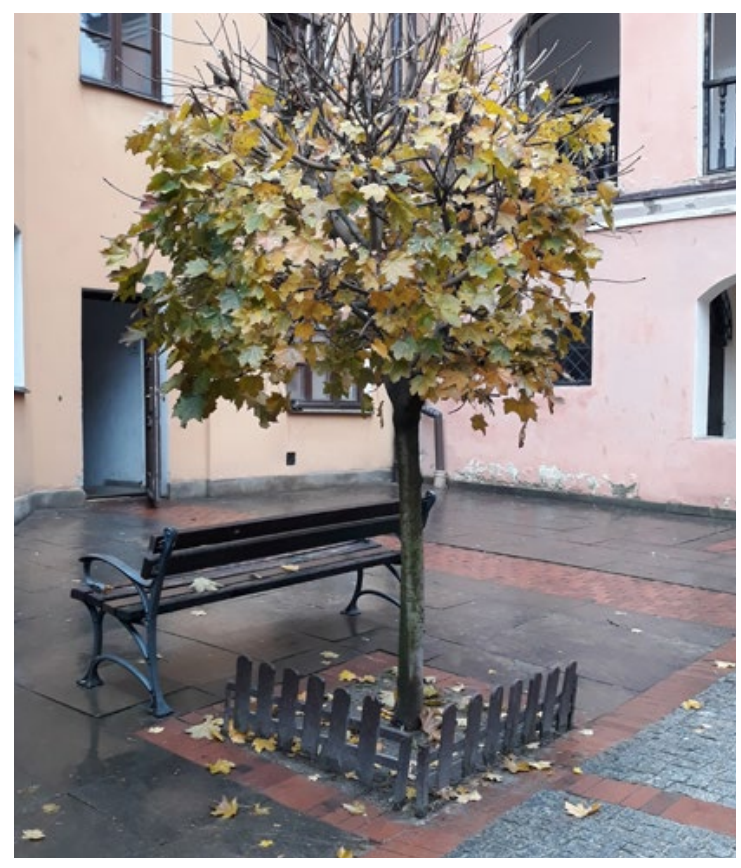

Fig. 14. Courtyard No. VI, Possible tight, infiltration reservoir; Source: author's own photo

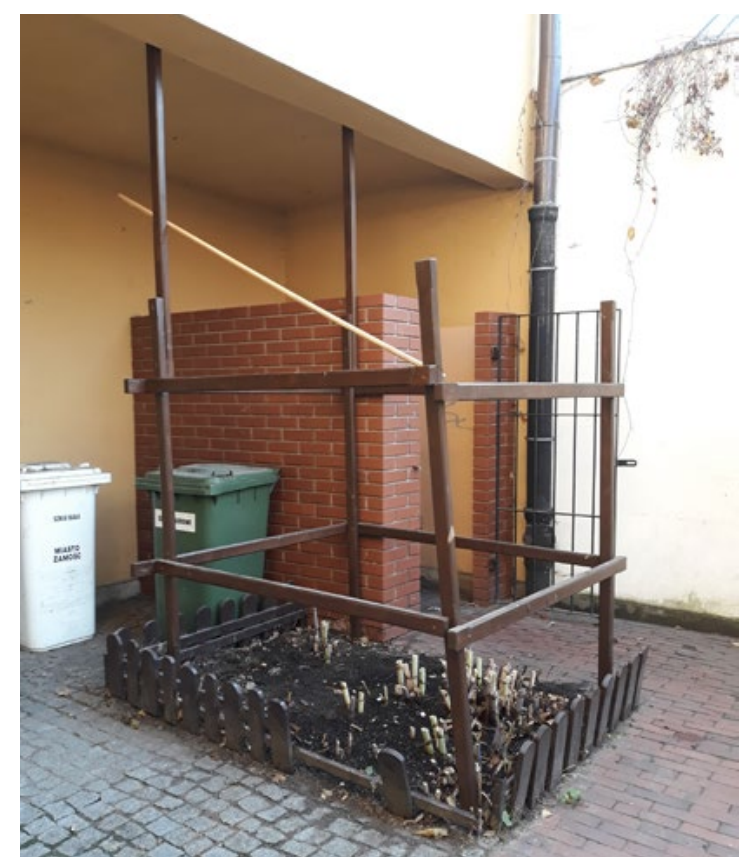

Fig. 15. Courtyard No. VI, Possible location for rain garden; Source: author's own photo

Current system of managing rainwater:

- Down pipes which collect rainwater from the roof gutters sink beneath the ground and connect to the sewerage, closed system

- Insufficient number and size of the existing drain collectors

- Poor maintenance of the existing collectors (garbage, leaves, remnants of ciggaretes clotting/ blocking the collector inlets 
Extensive pavement, relatively small, compacted surface allows for rapid runoff and irreversible waste of rainwater which might as well be reused for watering the plants

- The current system adds little to the aesthetics of the places

- Some courtyards are 'sunk' taking into account the levels of the surrounding streets, there is a potential risk of the storage/ inflow capacity turning out insufficient for a certain amount of sewage

- Uneven, rough paved courtyard surface halts water and results in puddles

- Lowered groundfloor areas, open, steep basement staircases, flooded in case of unexpected, rapid water downfalls

Common greenery and soil characteristics:

- In spite of vast variety of plant species present in the spaces, the overall outlook seems to lack conscous plan or design, though the first impression is quite a pleasant one

- Presence of ivy species that cover the walls and hang over the entrances to the buildings

- Plants play primarily aesthetical role, not enough attention is given to their pro - ecological parameters such as water retention, phytoremediation or rehabilitation impact they can have on the people living in the nearby tenement houses

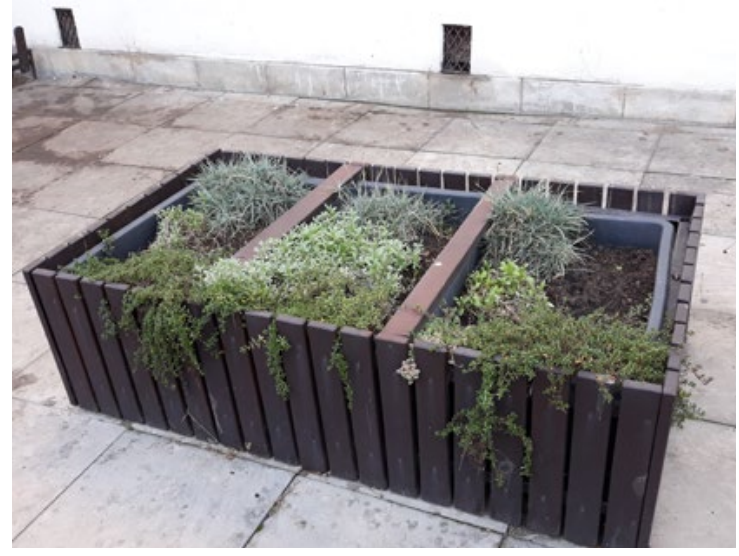

Fig. 16. Courtyard No. VI, The existing containers for plant cover and prospective rain garden implementation; Source: author's own photo

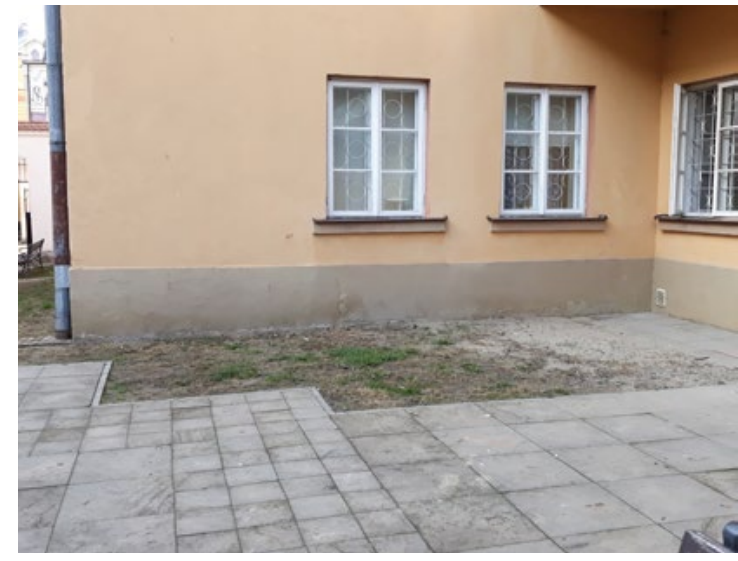

Fig. 17. Courtyard No. Vl; Unused green space suitable for the introduction of rain garden; Source: author's own photo

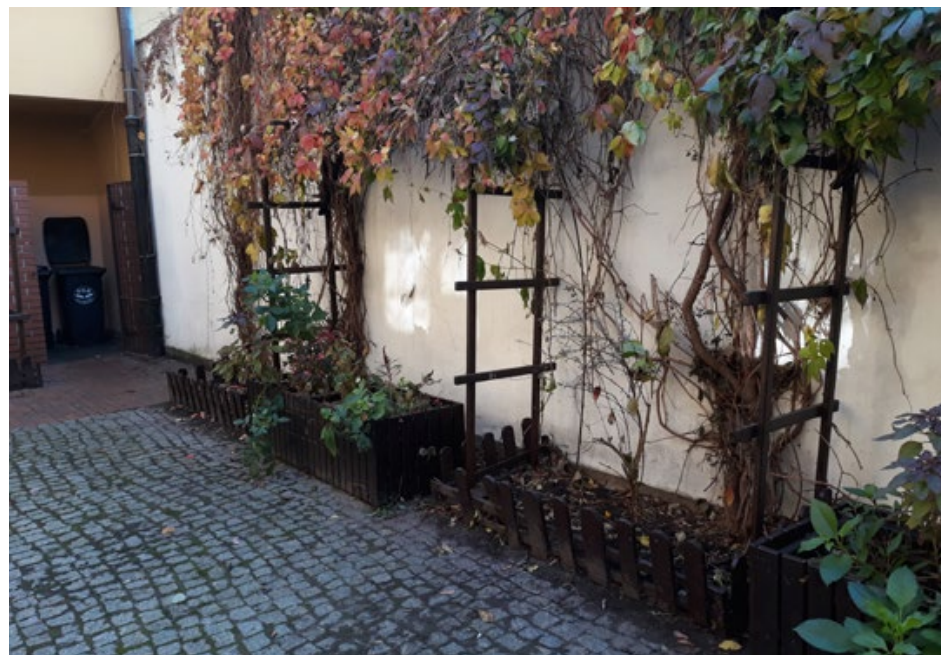

Fig. 18. Courtyard No. VI The existing greenery, the possibility of supplementing it with hydrophyte species of plants; Source: author's own photo

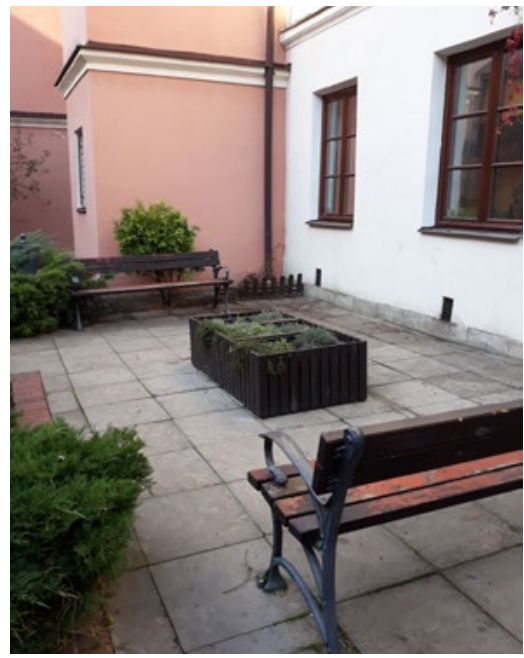

Fig. 19. Courtyard No. VI, The arrangement of greenery; Source: author's own photo 


\section{The soil profile and water conditions}

The author availed herself of the geological document prepared for the terrain around the streets of Królowej Jadwigi and Zamkowa issued in April 2013. The materials were handed in by the co-working design studio who undertook the project for the streets in question. On that particular terrain which is situated in the proximity of the analysed courtyards, soil conditions were marked as complex with a significant amount of moist and high plasticity whereas below $1.5-2.3 \mathrm{~m}$ - wet, soft plastic in shaped into loose, uncompacted embankment made of clay and debris. The native soil profile consists of loessial-like fines with expansive/ swelling capacity (heave soil). No ground water was found up to $3.0 \mathrm{~m}$, however, bottom-to-top filtration processes were observed which contribute to loosening top layer soils. Soil freezing depth was estimated at $1.0 \mathrm{~m}$ under the surface. Taking into account the aforementioned soil condtions, it is advisable to introduce leakproof, tight, impermeable rain garden either in the form of ground basin or as a above ground, aesthetical container.

Having analysed the aformentioned factors it is reasonable to introduce the system of rain garden as the one with the easiest implementation and fitting into the existent surface layout. By using those squared ground slots, the amount of groundwork is limited to minimum which is cost-effective and, what is more, it does not damage the paved surface to a large extent.

\section{What is rain garden? How is it applicable in these particular spaces?}

Rain gardens are one of the methods of accumulating, purifying rainwater channeled both from rooftops and paved surfaces. They can be of different shapes and sizes, designed both in the ground and separate containers, easily suited into the existing paved surface.. While intended in the ground, they can be connected in a system of several units which allows for an easy transportation of any surplus of rainwater. This system might be supleted with the one for capturing rainwater and putting it to good use by watering plants present in the vicinity. Rain gardens treat contaminated rainwater via hydrophytic species of plants that are grown within the unit. The inflow to the garden may be positioned above or underground allowing for greater variation in the system easthetics. The surface needed for the garden is directly related to the roof surface being estimated at $2 \%$ of a total roof surface. The section provided shows the subsequent layers of geological material with the top layer being coarse gravel which facilitates the infiltration of water. The percolation of water happens gradually with the excess of it flowing through a supplementary pipe positioned at the bottom of the basin right to a sewerage system.

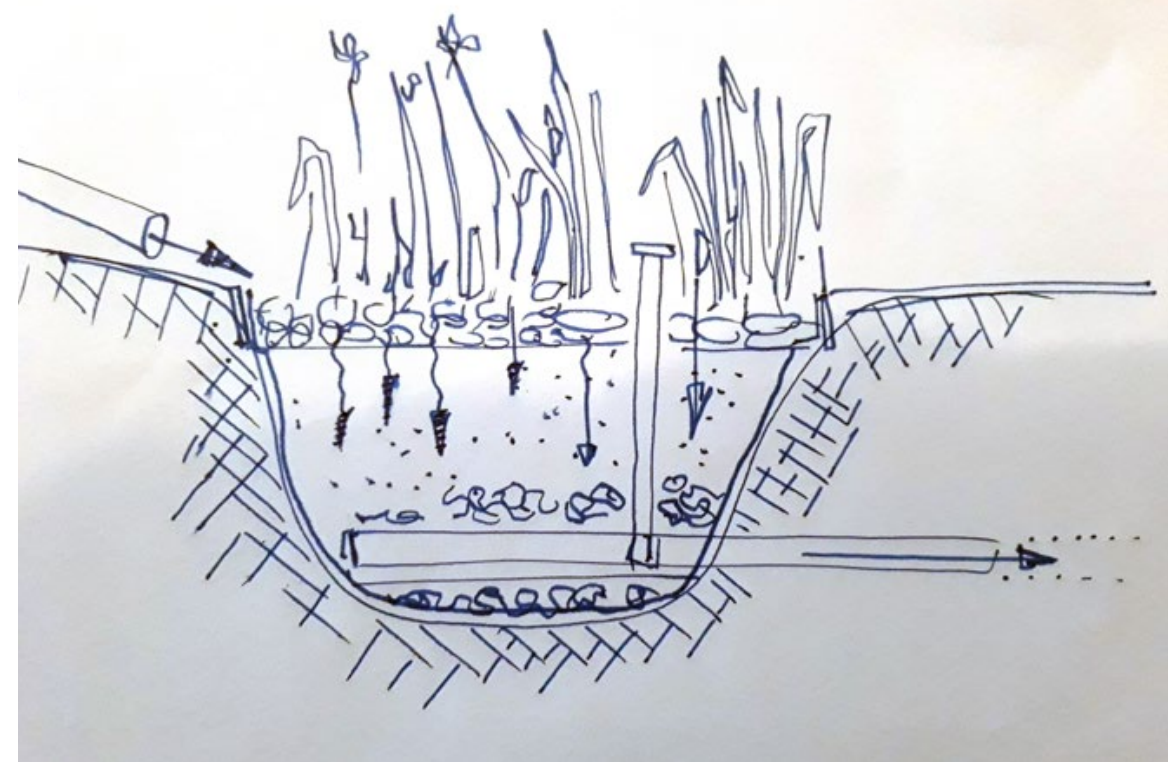

Fig. 20. Rain water garden schematic representation; Source: author's own material based on Schematic section from The Sendzimir Foundation 
There are two types of rain water systems; one with permeable outer surface chosen for the permeable soils (some fractions of sand, gravel) with higher infiltration capacity or another tight, leakproof system which accumulates rainwater, cleanses it and directs it to a traditional sewage system. Rain gardens aim at capturing water at its source preventing it from turning into sometimes uncotrollable runoff. Not only does the system manage rainwater but it also adds diversity of plants which make the place more attractive and pleasant to stay in. Carefully selected plant compopnents (and their roots) solidify the soil structure, are both draught and moisture tolerant. Such systems have this potential of reinvigorating local ecology and raising awareness of issues related to smart, permaculture solutions. They fulfill the principles of permaculture such as Catch and Store Energy, Produce no Waste (unless it is connected to the system of water harvesting), Integrate rather than Segregate, Use Small and slow solutions, reuse, recycle.

\section{The social aspects and reasons for the introduction of proposed changes}

Permaculture design strategies include the involvment of a community in the process of changing immediate environments. Therefore, the engagement of average local resident of the places discussed might stimulate their working capacities and restore self value hence the Old Town District (Stare Miasto District) has been rated the lowest position in the chart summarising the districts' performance in key social parameters such as:

- people affected by social problems (the greatest ratio of 60 people per 100 Old Town locals)

- domestic violence [14]

Therefore, Stare Miasto is the first among three degraded areas, the rest being Promyk District and Planty District) to undergo the process of revitalisation within the time span of 2017-2023. As far as the technical condition of infrastructure and development, The Old Town was described as the poorest with the age of 156 years. This is the part of the town with the highest domestic violence instances ( 6 children per 1000 people) and the greatest unemployment level (12 people per 100). The area selected for the revitalisation process spreads over 132 ha with 5239 residents. The establishment of revitalisation areas was followed by a survey conducted between 01.01.2017-31.03.2017, prepared by the Revitalisation Board. They collected 679 filled-in survey sheets, out of 1100 distributed. Among the most problematic social issues noticed by the respodents were unemployment rates (almost $20 \%$ of the people questioned). Additionally, in the section of the most pressing social problems, people mentioned high crime rates, emigration of young people and families with children, low engagement in public and cultural life of the Town, the problem of ageing society, poor integration among the citizens, poverty. As far as environmental concerns, 35,15\% of those who responded reported citizens' tendency to express unecological behaviour (the problem selected as the one requiring the most immediate attention), $23,89 \%$ were of the opinion that air pollution is the most detrimental to their health while $14,66 \%$ of people surveyed indicated low quality of water reservoirs and watercourses together with high degree of water contamination. $13,30 \%$ of respondents disapproved of insufficient or bad condition of green zones/ areas. In the domain of spacial and functional problems of Zamość, survey participants $(23,4 \%)$ perceived deficits in the quantity and quality of technical infrastructure: railway, road, water-and-sewage management systems. What is also symptomatic, the most acute problem concerning the condition of built develompent and building structures was insufficient amount of energy-efficient, pro-eco, sustainable equipment. All the numerical data come from "The Local Revitalisation Program for Zamość for the period 2017 to 2023 which has been updated and is widely available on the website: http://rewitalizacja.zamosc.pl/.

The suitability and permaculture value of a chosen system for sustainable water management can be supported by the following outcomes and advantages:

- the system improves the quality of rainwater by alleviating its pollution - the engagement of phytoremediation processes [7]

- reduces the risk of urban flooding by means of collecting water at the source rather than allowing for uncontrollable runoff; see spatial characteristics of the analysed courtyards

- the physical introduction and later maintenance of the system might be ordained and conducted by the most immediate community members living around the courtyard (high percentage of residential units) - such actions fall under the concept of hortitherapy; 
- creating work opportunities for the unemployed living nearby

- boosting integration and reponsibility among community members, gathered around the goal of making a common space healthier and more aesthetically pleasing (fulfilling the social aspect of permaculture principle: Integrate rather than Segregate

- proposed changes offer multi-dimensional response to issues stated in the Program survey

- the introduction of the system might spark citizens' awareness and interest in pro-ecological behaviour as well as spread knowledge of the importance of plant cover for physical and mental well-being

- the system would use the existing fragments of exposed soil layer as well as already implemented piesec of street furnishing such as brick wells, plant containers, wooden fencing,

- the introduction of plants with hydrophytic qualities which are at the same time the elements of a traditional Renessaince garden [...] such as for example: Iris germanica, Iris pseudacorus, Iris sibirica, Viola palustris

\section{Bibliography}

[1] Fundacja Sendzimira, Ogrody deszczowe w pojemnikach, Instrukcja budowy Sendzimir Foundation, Rain Gardens in containers. Construction manual

[2] Planter box raingarden instruction sheet; http://www.melbournewater.com.au/getinvolved/protecttheenvironment/ raingardens/Pages/How-do-I-build-a-raingarden.aspx

[3] Rain garden in 5 steps, Gdańskie Wody

[4] Woods-Ballard, B.; Kellagher, R; Martin, P.; Jefferies, C.; Bray, R.; Shaffer, P. (2007): The SUDS manual. London: CIRIA

[5] Soil Science Society of America, Soil Basics; https://www.soils.org/discover-soils/soil-basics, webpage access: $9^{\text {th }}$ Nov. 2018

[6] Furmanik, B.; Dobory materiałowe w ogrodach zabytkowych, Kurier Konserwatorski (2010)

[7] Phytoremediation: An Environmentally Sound Technology for Pollution Prevention, Control and Remediation, An Introductory Guide To Decision-Makers, Newsletter and Technical Publications, Freshwater Management Series No. 2; http://www.unep.or.jp/ietc/publications/freshwater/fms2/1.asp; webpage access: $9^{\text {th }}$ Nov. 2018

[8] http://www.floodsite.net/juniorfloodsite/html/en/teacher/thingstoknow/hydrology/urbanfloods.html; webpage access: $9^{\text {th }}$ Nov. 2018

[9] http://permacultureprinciples.com

[10] Raport z wykonania Programu Ochrony Środowiska dla Powiatu Grodzkiego Zamość za lata 2014-2015

[11] Poleto, C.; Tassi, R.; Sustainable Urban Drainage Systems, Federal University of Technology - Parana (UTFPR), Federal University of Santa Maria (UFSM), Brazil, IntechOpen

[12] Lejcuś, K.; Burszta-Adamiak, E.; Dąbrowska, J; Wróblewska, K.; Orzeszyna, H.; Śpitalniak, M.; Misiewicz, J.; Katalog dobrych praktyk - zasady zrównoważonego gospodarowania wodami opadowymi pochodzącymi z nawierzchni pasów drogowych, Wrocław 2017, Uniwersytet Przyrodniczy, Wrocław

[13] Holmgren, D, 2013.; 'Essence of Permaculture A summary of permaculture concepts and principles taken from 'Permaculture Principles and Pathways Beyond Sustainability',

[14] "The Local Revitalisation Program for Zamość for the period 2017 to 2023, updated: http://rewitalizacja.zamosc.pl/.; webpage access: $7^{\text {th }}$ Nov. 2018

[15] Drapella-Hermansdorfer A., 2005: Greenery-Water-Space Recycling: Selected aspects of natural revitalization of cities, Teka Kom. Arch. Urb. Stud. Krajobr.-OL PAN, Wrocław University of Technology, 35-43,

[16] Drapella-Hermansdorfer, A.; Ecodistrict as an element of modern urban theory and praxis, Technical Transactions, Architecture, Cracow University of Technology, Issue 11 Year 108

[17] Mollison, B.;

[18] Brain R., Thomas B., 2013,: Permaculture, Utah State University, Extension Sustainability, Environment and Society Faculty Publications, 12-2013

[19] The soil conditions data is gathered from the local design office who took part in the work on Zamkowa and Królowej Jadwigi Streets

[20] : http://rewitalizacja.zamosc.pl/. Webpage access: $10^{\text {th }}$ Nov. 2018

[21] Holmgren D.: Permaculture. Principles \& Pathways Beyond Sustainability

[22] Holmgren D.: Permaculture Ethics and Design Principles, A Presentation by David Holmgren 